\title{
Endocrine complications of cancer immunotherapy
}

\author{
Aleksandra Król, Tomasz Gawlik, Barbara Jarząb \\ Department of Nuclear Medicine and Endocrine Oncology, Maria Skłodowska-Curie Institute — Oncology Centre, Gliwice Branch, \\ Gliwice, Poland
}

\begin{abstract}
Immunotherapy using monoclonal antibodies - checkpoint inhibitors - is a dynamically evolving discipline of clinical oncology and a new hope for patients with advanced and disseminated cancer. However, the activation of T-lymphocytes can at the same time lead to autoimmune response and destruction of healthy organs, which is a serious adverse effect that can also affect the endocrine system. Here we present possible endocrine complications of immunotherapy with contemporary inhibitors of immune checkpoints (CTLA-4, PD-1, PD-L1/L2), their frequency, symptoms, and proposed grade-dependent treatment.

Failure to diagnose endocrine pathology can in adverse circumstances lead to treatment failure and condemn the patient's fate.

Due to tremendous progress in cancer immunotherapy during the last few years and an increase in the number of treated patients, endocrinologists should become acquainted with the specificity of this mode of oncological treatment. (Endokrynol Pol 2018; 69 (6): 722-733)

Key words: immunotherapy; immune checkpoints inhibitors; endocrine complications
\end{abstract}

\section{Introduction}

For many years scientists have tended to use the inner forces of the immune system to fight diseases. Cancer has not been an exception; however, it was not until the introduction of monoclonal antibodies inhibiting immune checkpoints that a breakthrough in this field was made [1,2].

This novel therapy was first used to fight melanoma (ipilimumab - monoclonal antibody anti-CTLA-4, FDA approved in 2011). Subsequently, numerous attempts were made to use antibodies against novel molecules, as well as to cure other cancer types, including renal cancer, non-small-cell lung cancer, head and neck cancer, haematological neoplasms, etc. The American Society of Clinical Oncology recognised immunotherapy as the greatest achievement of 2015, 2016, and 2017 in cancer treatment. The number of clinical trials in this field indicates the growing interest and great hope attributed to this type of treatment [3].

On the other hand, immune system activation, being the effect of the therapy, can at the same time lead to major complications, including endocrine system disorders. Adverse reactions depend on the medication used as well as individual predisposition. Their first symptoms are often non-characteristic and tend to be attributed to the underlying disease. Knowledge of possible endocrine complications of immunotherapy is necessary to ensure the patients' safety, and due to their growing number it is necessary for every endocrinologist.

\section{Immunotherapy using inhibitors of immune response checkpoints}

A healthy human body can effectively fight foreign cells, including cancer cells. Cancer cells can escape immune surveillance by inhibiting the immune response and becoming invisible to the immune system. For over 100 years attempts have been made to use the patient's immune system to fight cancer, unfortunately without any major progress. Only during the last few years has precise knowledge about the roles of each of the complicated immune reaction participants allowed the rise of contemporary immunotherapy. Immunocompetent cells, their roles and interactions, as well as the mechanisms of escape from immune surveillance have only recently been understood. This knowledge, gained in the last years, has facilitated therapy based on monoclonal antibodies blocking the checkpoints of immune response. For its action, the immune system needs either an effective mechanism of response induction or its limitation to avoid the threat of overreaction, which could be worse than the illness itself. The identification of the molecules that limit the immune response (immune response checkpoints) has enabled the invention of drugs that can effectively unlock the immune system and consequently restore efficient inner immune reactions. That achievement became the breakthrough event of contemporary immunotherapy [4].

T-lymphocyte activation leads to an increased expression of proteins able to inhibit their excess action.

Tomasz Gawlik, MD, Department of Nuclear Medicine and Endocrine Oncology, Maria Skłodowska-Curie Institute — Oncology Centre, Gliwice Branch, Gliwice, Poland, ul. Wybrzeże Armii Krajowej 15, 44-101 Gliwice, Poland, tel: +48 501275724 , fax: +48 32 278 9933 , e-mail: gawlik@mp.pl 


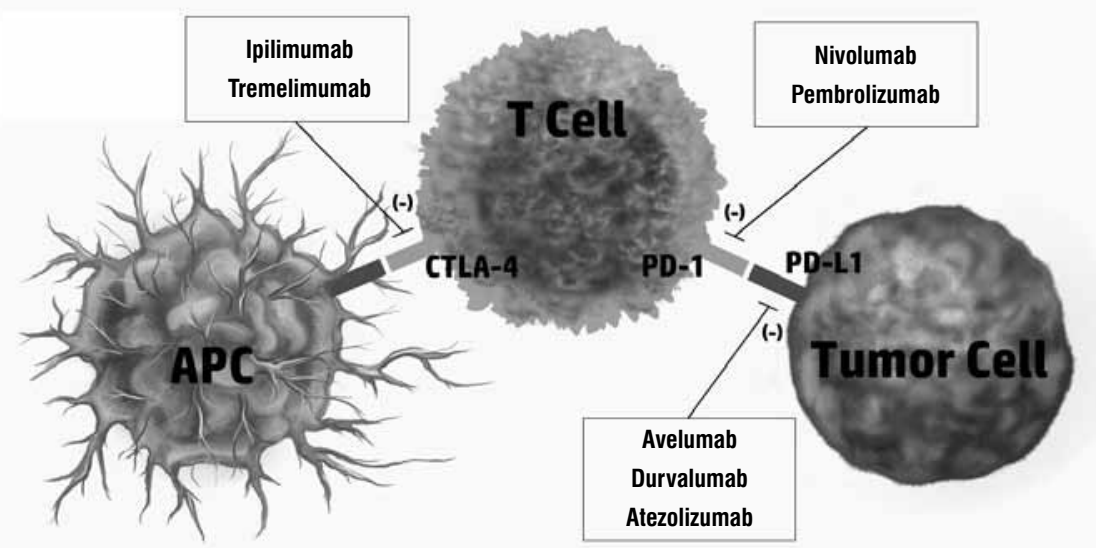

Figure 1. Immune checkpoints as targets for contemporary immunotherapy. CTLA-4 - cytotoxic T-cell antigen-4; PD-1 - programmed death receptor-1; PD-L1/L2 — programmed death receptor-1 ligand 1/2; APC — antigen-presenting cell

These proteins are called immune checkpoints. One of them is CTLA-4 (cytotoxic T-cell antigen-4), discovered in 1987. Its ligands are CD80 and CD86, molecules that are present on the surface of antigen-presenting cells (APCs). Weak CTLA-4 expression is connected with increased autoimmune diseases incidence [5-7], including autoimmune thyroid disorders $[8,9]$.

Monoclonal antibody directed against CTLA-4 was the first immune checkpoint inhibitor used to treat melanoma in clinical trials initiated in 2007 [10] and registered by FDA in 2011.

Another immune checkpoint protein is PD-1 (programmed death receptor-1), expressed on T-lymphocytes, B-lymphocytes, as well as monocytes/macrophages. Overly increased action of T-lymphocytes against their own tissues is inhibited by binding the protein with its ligands (PD-L1 and PD-L2) present on the surface of its own cells. These ligands were also found on the cancer cell surface, allowing them to escape the immune system response. Their presence also allowed for treatment based on the inhibition of either PD-1 (e.g. nivolumab, pembrolizumab) or PD-L1 (e.g. atezolizumab, durvalumab). These drugs given alone or together with CTLA-4 inhibitor nowadays constitute important treatment regimens in melanoma, renal cell cancer, or non-small cell lung cancer (Fig. 1). The efficacy of antibodies to PD-1 or PD-L1 is dependent on the presence of respective surface proteins on cancer cell. The mutation load is also an important response prognostic factor. Generally, the more mutations, immunogenic neo-antigens, microsatellite instability (MSI), and deficiency DNA mismatch repair (dMMR), the more frequent and longer the response to the treatment [11, 12].

Other trials that are still ongoing focus on different lymphocyte surface molecule inhibitors such as TIM-3 and LAG-3, or agonists of co-stimulatory proteins that can prove their effectiveness in the future $[13,14]$.

\section{Immune-related adverse events (irAEs)}

Immune-related adverse events (IrAEs) can potentially affect all organs. The toxicity of immunotherapy is different in its nature from other anti-cancer therapies. It is specifically connected with the mechanism of the treatment involving stimulation of the immune response, infiltration of the organs by the activated T-lymphocytes, and targeted, specific autoimmune reaction. Due to the presence of immune checkpoints in the whole organism, the adverse reactions can also be present in every organ. The most frequent are the complications involving skin, gastro-intestinal tract (including liver), endocrine glands, more seldom osteoarticular, respiratory, cardiovascular, and nervous system as well as kidneys and different elements of the eye. Their frequency and grade depend on numerous factors connected with either the therapy (the medication used, combined therapy) or the patient (expression of the target checkpoint protein, individual characteristics, status of the immune system before commencing the therapy, pre-existing autoimmune conditions) [15]. The trials on pre-treatment identification of possible future therapy-driven adverse outcomes, defining possible predicting biomarkers to identify at-risk patients and enable early adverse reaction detection, are still ongoing $[16,17]$. Additionally, trials on the influence of external factors, such as diet, smoking status, or gut microbiome, are also in progress $[18,19]$.

As already mentioned, immunotherapy complications can manifest with great variation in terms of location, frequency, and time from commencing the treatment. The adverse events toxicity grade (generally 
assessed according to CTCAE - Common Terminology Criteria for Adverse Events, which will be discussed further below) determines actions needed to be undertaken, including in some cases the cessation of therapy [20-23].

The most frequent AEs are skin reactions such as itching, rash, vitiligo, photosensitivity, alopecia, and others. They are the first to appear (2-3 weeks from the start of treatment) in more than $50 \%$ of patients. They manifest more frequently during the treatment with CTLA- 4 inhibitors. Most of them are benign and resolve after applying antihistamines or corticosteroids and do not require the discontinuation of treatment.

The adverse reactions in the alimentary system (diarrhoea, abdominal pain, vomiting, intestinal mucous inflammation) are frequent, with varying grades. They appear predominantly during combined treatment with anti-CTLA- 4 and anti-PD- 1 antibodies, affecting $45 \%$ of patients. In high-grade reactions or in the case of colitis, they require discontinuation of treatment, intravenous administration of corticosteroids, and, in some cases, immunosuppressive drugs. These kinds of complications are significantly less frequent during treatment with novel anti-PD-L1 inhibitors (e.g. for durvalumab they appear in only $2 \%$ ) [24-26].

The liver complications should be sought for and monitored during each cycle of therapy, as they are frequent and initially asymptomatic. SGOT and SGPT assay is sufficient. The complications appear in 5-10\% of patients during monotherapy and $25-30 \%$ of patients on combined therapy.

The next group comprise endocrine complications, which are thoroughly described in the next section. They appear in about $10 \%$ of patients with great diversity depending on the specific drugs and the gland involved. In general, they have non-characteristic initial presentation and unnoticeable course until serious complications with long-lasting reconvalescence or even definite dysfunction of involved organs requiring hormonal substitution.

Musculoskeletal or rheumatologic complications were described in 2 to $12 \%$ of treated patients, usually as vasculitis, inflammatory arthritis, or myositis of benign nature. They usually resolve quickly after treatment with corticosteroids.

Less frequent are the complications involving lungs (including interstitial inflammation), kidneys (frequently only manifesting as abnormal GFR), and nervous system (less than $1 \%$ of treated patients) involving polyneuropathy, optic nerve inflammation, Guillian-Barre syndrome, myasthenia, and aseptic meningitis. Rarely, adverse reactions involve the heart (e.g. rhythm perturbation with clinical course similar to myocarditis or cardiomyopathy), pancreas, and eyes (keratitis, uveitis, conjunctivitis, episcleritis).
There are observations that the appearance of side effects during the immunotherapy (unless, of course, they require the discontinuation of therapy) can indicate greater efficacy of the treatment. The prospective trials on the correlation between $\mathrm{AE}$ incidence and the treatment efficacy are still ongoing [20-23, 27].

\section{The endocrine adverse reactions}

The endocrine adverse reactions during immunotherapy are frequent and appear usually after 7-20 weeks. Immunotherapy involving anti-CTLA- 4 or combined therapy involving the antibody can evoke hypopituitarism due to hypophysitis, whereas during anti-PD-1 and anti-PD-L1/L2 therapy thyroid disorders (mainly hypothyroidism) are often observed. Each endocrine organ can be affected by AEs, including the adrenal cortex (either secondary or primary, life threatening insufficiency), which is essential for patient health. Less frequent are type 1 diabetes and hypoparathyroidism [28].

An important feature of endocrine complications is their non-characteristic initiation, frequently attributed to the underlying disease itself. One has to keep in mind that, contrary to the everyday practice, one is not dealing with a previously healthy patient in whom the symptoms appear instantly. Here the first symptoms such as fatigue, weakness, loss of appetite, and change in body mass can be attributed to the underlying cancer $[28,29]$. Hence one should actively seek the symptoms of hormonal dysfunction, especially taking precise history during each cycle and ordering additional biochemical tests when needed.

As mentioned above, the intensity of the adverse reaction is generally assessed according to Common Terminology Criteria for Adverse Events (CTCAE) scaling from 1 to 5 (latest version 5.0 dated November 27, 2017). Grade 1 denotes nonsymptomatic deviation in a laboratory test, grade 2 - moderate symptoms, grade 3 - severe symptoms frequently requiring admission to the hospital, grade 4 means life-threatening adverse reaction, and grade 5 - death due to AE. Endocrine AEs are usually classified as grade 1-2 and do not require definite discontinuation of immunotherapy. Nevertheless, a lot of patients suffer from serious AEs, particularly in the case of late diagnosis, which can possibly result in the necessity of immunotherapy discontinuation and the therapy with high dose corticosteroids or can even pose a life-threatening condition (1-2\% of patients) [28].

\section{Pituitary complications}

Pituitary dysfunction as a complication of immunotherapy affects $1.5-17 \%$ of patients treated with an- 
ti-CTLA-4 antibody alone or in combination with other medications. It appears more often in men and in the elderly. The symptoms appear usually after two months of treatment and can be the result of the mass effect caused by pituitary gland enlargement (headache, vision disturbances) or insufficient hormone production (fatigue, tiredness, loss of appetite). Local symptoms require excluding brain metastases and aseptic meningitis [30, 31].

In most patients, characteristic presentation in MRI is seen. The pituitary gland is enlarged as a result of infiltration by immunocompetent cells [32, 33]. Laboratory results usually show changes typical for anterior lobe insufficiency for all axes. Isolated GH or PRL deficiency is seen less frequently. Posterior lobe insufficiency has not been observed in this setting. Every toxicity above grade 2, meaning the presence of local symptoms or hormonal deficiency, requires the interruption of immunotherapy. In the case of mass effect, particularly vision problems, urgent therapy with intravenous steroids is required (e.g. hydrocortisone $50-100 \mathrm{mg} 3-4$ times a day or an equivalent dose of methylprednisolone). In moderately severe symptoms oral corticosteroids are usually enough (e.g. hydrocortisone $20-30 \mathrm{mg}$ in split doses or prednisone/prednisolone in equivalent dose). Substitution therapy with respective hormones should be used, in the same manner as in other forms of hypopituitarism. Long lasting hormonal deficiency is typical for this form of hypopituitarism, despite discontinuation of the therapy and resolution of the lesions seen in MRI. This particularly applies to adrenal insufficiency and, to a lesser extent, to thyroid and gonads, and consequently leads to prolonged necessity of hormonal substitution.

Hypopituitarism appears incidentally as a consequence of anti-PD-1 or anti-PD-L1 therapy in less than $1 \%$ of treated patients (in durvalumab therapy less than $0.1 \%$ ). Therefore, pituitary complications should be mainly expected during treatment with ipilimumab alone or in combination with other drugs $[28,30,31,34]$.

\section{Disorders of thyroid function during immunotherapy}

Aberrant thyroid function, mainly hypothyroidism, is frequent (> 10\% treated) during PD-1 and PD-L1/L2 inhibitor therapy (nivolumab, pembrolizumab, atezolizumab, durvalumab). During anti-CTLA-4 treatment such complications depend on the dose and are seen in $1-5 \%$ patients on standard dose or in up to $10 \%$ on ipilimumab $10 \mathrm{mg} / \mathrm{kg}$. Combined therapy (e.g. ipilimumab + nivolumab) increases the risk to over $20 \%$. One should remember about the possible occurrence of secondary hypothyroidism due to the abovementioned hypophysitis.

Thyroid-related adverse reactions encompass persistent or transient hypothyroidism, hyperthyroidism during painless thyroiditis, and manifestation of Graves' disease, including thyrotoxic crisis or orbitopathy. In most patients with thyroid complications concentrations of anti-thyroid antibodies (anti-TPO and anti-TG) are elevated. However, their role as risk factors for incidence of thyroid dysfunction or its duration has not yet been confirmed.

The time from the beginning of immunotherapy until the manifestation of thyroid dysfunction varies from several days to over a year, with median value of ca. three months. The complications appear more often in women, in most cases are classified as grade 1 or 2 , and do not require discontinuation of immunotherapy.

Considering treatment options, one should take into account symptoms and hormonal test results. In the case of asymptomatic TSH elevation below $10 \mathrm{uIU} / \mathrm{ml}$, thyroxine substitution as well as immunotherapy discontinuation is not necessary; however, close monitoring of thyroid function is advised before each cycle. The cause of hyperthyroidism should be differentiated between Graves' disease and destructive inflammation. The assessment of thyroid antibodies, including anti-TSH receptor antibodies and thyroid scintigraphy, is suggested as well as diagnosis-dependent treatment (glucocorticoids, betablockers, less frequently anti-thyroid drugs).

One should also keep in mind the possibility of secondary hypothyroidism occurrence due to hypopituitarism, and in each case of low TSH accompanying low fT4 the pituitary-adrenal axis should be assessed.

Primary hypo- or hyperthyroidism is often transient and often requires follow-up laboratory testing both during and after treatment or medication change [28, $35,36]$.

\section{Immunotherapy-induced adrenal insufficiency}

Adrenal insufficiency can be the first manifestation of hypopituitarism during immunotherapy. Its frequency is comparable with hypopituitarism itself because it appears in $75 \%$ of such patients.

Immunotherapy can also cause primary adrenal insufficiency, although less frequently (up to $2 \%$; in the majority of trials less than $1 \%$ ). The first sign of imminent adrenal insufficiency is frequently asymptomatic hyponatraemia, which makes routine serum electrolyte testing mandatory.

Adrenal complications in most patients require discontinuation of immunotherapy because in the 
majority of them the toxicity reaches grade 3, requiring admission to the hospital. In some patients, adrenal enlargement was observed in imaging studies, fulfilling criteria for adrenalitis. The treatment is typical for primary adrenal insufficiency. One should not forget mineralocorticoid supplementation $[28,36]$.

\section{Other, less frequent endocrine complications}

Diabetes is a rare complication of immunotherapy. Its incidence in this setting is below 1\%, mainly in patients treated with anti-PD-1 antibody (e.g. nivolumab $0.9 \%$, pembrolizumab $0.2 \%$, avelumab $0.1 \%$ ). It usually reaches grade 3 with glucose concentration above $250 \mathrm{mg} \%$, requiring interruption of immunotherapy and administration of insulin, as in type 1 diabetes.

There are single case reports describing other adverse effects, like acute hypocalcaemia as a consequence of hypoparathyroidism during combined treatment with ipilimumab and nivolumab [37-39].

\section{Cooperation between the endocrinologist and oncologist}

Therapy with immune checkpoints inhibitors is administered in specialised oncological centres (about 20 centres currently in Poland). The patients are supervised by clinical oncologists, who are responsible for proper qualification and safe treatment, including early and pertinent recognition of adverse effects. Drug programs contain requirements to perform screening laboratory tests, related also to endocrine function, which help to detect the most frequent complications. As was mentioned earlier, some grade 1 and 2 complications do not require treatment. Often the oncologist him/herself orders the treatment, as in the case of benign primary hypothyroidism. In centres where specialist consultation is possible, the patient can be attended to by a multidisciplinary team. That can be a great support for clinical oncologists, especially in difficult cases requiring extensive knowledge and experience in a specific field. The patient with full-blown hypopituitarism or primary adrenal insufficiency should certainly be treated by an endocrinologist. The decision concerning discontinuation of immunotherapy or its postponement is at the discretion of the oncologist, but the opinion of the endocrinologist in this case is crucial.

As mentioned, a lot of endocrine complications of immunotherapy are permanent, meaning that irrespective of the termination, interruption, or change in oncologic therapy the substitution therapy will be supervised by the patient's endocrinologist.

\section{Conclusions}

It is our hope that future advancements in immunotherapy will bring medications with fewer adverse effects. However, the frequent administration of combined therapy and broadening of indications to use the therapy in other cancers cause the number of treated patients to increase rapidly. In the near future both oncologists and endocrinologists will have to face many incidents of treatment-related endocrinopathy. It is essential for specialists from both fields to band together and come up with combined therapies for the greater good of the patients.

Although currently the problem of endocrine complications of immunotherapy seem distant and irrelevant for many endocrinologists, immunotherapy with all its prospective advantages and threats is right on our doorstep, and we have to be prepared.

\section{Funding sources: none}

\section{References}

1. Farkona S, Diamandis EP, Blasutig IM. Cancer immunotherapy: the beginning of the end of cancer? BMC Med. 2016; 14: 73, doi: 10.1186/s12916-016-0623-5, indexed in Pubmed: 27151159.

2. Joshi M, Pal SK, Drabick JJ. Novel approaches in cancer immunotherapy - a light at the end of the tunnel. Discov Med. 2016; 21(118): 479-487, doi: 10.18356/d63d67dc-en, indexed in Pubmed: 27448784.

3. Heymach J, Krilov L, Alberg A, et al. Clinical Cancer Advances 2018: Annual Report on Progress Against Cancer From the American Society of Clinical Oncology. J Clin Oncol. 2018; 36(10): 1020-1044, doi: 10.1200/JCO.2017.77.0446, indexed in Pubmed: 29380678.

4. Li X, Shao C, Shi Y, et al. Lessons learned from the blockade of immune checkpoints in cancer immunotherapy. Hematol Oncol. 2018; 11(31): 1-26, doi: 10.1186/s13045-018-0578-4.

5. Wang Ke, Zhu Q, Lu Y, et al. CTLA-4 +49 G/A Polymorphism Confers Autoimmune Disease Risk: An Updated Meta-Analysis. Genet Test Mol Biomarkers. 2017; 21(4): 222-227, doi: 10.1089/gtmb.2016.0335, indexed in Pubmed: 28384040.

6. Chen Z, Fei M, Fu Da, et al. Association between cytotoxic T lymphocyte antigen-4 polymorphism and type 1 diabetes: a meta-analysis. Gene. 2013; 516(2): 263-270, doi: 10.1016/j.gene.2012.12.030, indexed in Pubmed: 23261825 .

7. Houcken J, Degenhart C, Bender K, et al. PTPN22 and CTLA-4 Polymorphisms Are Associated With Polyglandular Autoimmunity. J Clin Endocrinol Metab. 2018; 103(5): 1977-1984, doi: 10.1210/jc.2017-02577.

8. Tokić S, Štefanić M, Karner I, et al. Altered expression of CTLA-4, CD28, VDR, and CD45 mRNA in T cells of patients with Hashimoto's thyroiditis - a pilot study. Endokrynol Pol. 2017; 68(3): 274-828, doi: 10.5603/EP.2017.0020, indexed in Pubmed: 28660994.

9. Gu Lq, Zhu W, Zhao Sx, et al. Clinical associations of the genetic variants of CTLA-4, Tg, TSHR, PTPN22, PTPN12 and FCRL3 in patients with Graves' disease. Clin Endocrinol (Oxf). 2010; 72(2): 248-255, doi: 10.111 1/j.1365-2265.2009.03617.x, indexed in Pubmed: 19438904.

10. Cranmer LD, Hersh E. The role of the CTLA4 blockade in the treatment of malignant melanoma. Cancer Invest. 2007; 25(7): 613-631, doi: 10.1080/07357900701522315, indexed in Pubmed: 18027152.

11. Dudnik E, Peled N, Nechushtan H, et al. Israel Lung Cancer Group. BRAF Mutant Lung Cancer: Programmed Death Ligand 1 Expression, Tumor Mutational Burden, Microsatellite Instability Status, and Response to Immune Check-Point Inhibitors. J Thorac Oncol. 2018; 13(8): 1128-1137, doi: 10.1016/j.jtho.2018.04.024, indexed in Pubmed: 29723688.

12. Teixidó C, Vilariño N, Reyes R, et al. PD-L1 expression testing in non-small cell lung cancer. Ther Adv Med Oncol. 2018; 10: 1758835918763493, doi: 10.1177/1758835918763493, indexed in Pubmed: 29662547.

13. Du W, Yang M, Turner A, et al. TIM-3 as a Target for Cancer Immunotherapy and Mechanisms of Action. Int J Mol Sci. 2017; 18(3): 645, doi: 10.3390/ijms18030645, indexed in Pubmed: 28300768.

14. Imai $\mathrm{Y}, \mathrm{Hasegawa} \mathrm{K}$, Matsushita H, et al. Expression of multiple immune checkpoint molecules on $\mathrm{T}$ cells in malignant ascites from 
epithelial ovarian carcinoma. Oncol Lett. 2018; 15(5): 6457-6468, doi: 10.3892/ol.2018.8101, indexed in Pubmed: 29616115.

15. June $\mathrm{CH}$, Warshauer JT, Bluestone JA. Is autoimmunity the Achilles' heel of cancer immunotherapy? Nat Med. 2017; 23(5): 540-547, doi: 10.1038/nm.4321, indexed in Pubmed: 28475571.

16. Valpione S, Pasquali S, Campana LG, et al. Sex and interleukin-6 are prognostic factors for autoimmune toxicity following treatment with anti-CTLA4 blockade. J Transl Med. 2018; 16(1): 94, doi: 10.1186/s12967-018-1467-x, indexed in Pubmed: 29642948.

17. Anderson R, Rapoport BL. Immune Dysregulation in Cancer Patients Undergoing Immune Checkpoint Inhibitor Treatment and Potential Predictive Strategies for Future Clinical Practice. Front Oncol. 2018; 8: 80, doi: 10.3389/fonc.2018.00080, indexed in Pubmed: 29623257.

18. Calles A, Liao X, Sholl LM, et al. Expression of PD-1 and Its Ligands, PD-L1 and PD-L2, in Smokers and Never Smokers with KRAS-Mutant Lung Cancer. J Thorac Oncol. 2015; 10(12): 1726-1735, doi: 10.1097/JTO.0000000000000687, indexed in Pubmed: 26473645.

19. Humphries A, Daud A. The gut microbiota and immune checkpoint inhibitors. Hum Vaccin Immunother. 2018; 14(9): 2178-2182, doi: 10.10 80/21645515.2018.1442970, indexed in Pubmed: 29494275.

20. Rapoport BL, van Eeden R, Sibaud V, et al. Supportive care for patients undergoing immunotherapy. Support Care Cancer. 2017; 25(10): 3017-3030, doi: 10.1007/s00520-017-3802-9, indexed in Pubmed: 28707167.

21. Sosa A, Lopez Cadena E, Simon Olive C, et al. Clinical assessment of immune-related adverse events. Ther Adv Med Oncol. 2018; 10: 1-11, doi: 10.1177/1758835918764628, indexed in Pubmed: 29623110.

22. Michot JM, Bigenwald C, Champiat S, et al. Immune-related adverse events with immune checkpoint blockade: a comprehensive review. Eur J Cancer. 2016; 54: 139-148, doi: 10.1016/j.ejca.2015.11.016, indexed in Pubmed: 26765102.

23. Horvat TZ, Adel NG, Dang TO, et al. Immune-Related Adverse Events, Need for Systemic Immunosuppression, and Effects on Survival and Time to Treatment Failure in Patients With Melanoma Treated With Ipilimumab at Memorial Sloan Kettering Cancer Center. J Clin Oncol. 2015; 33(28): 3193-3198, doi: 10.1200/JCO.2015.60.8448, indexed in Pubmed: 26282644

24. Massard C, Gordon MS, Sharma S, et al. Safety and Efficacy of Durvalumab (MEDI4736), an Anti-Programmed Cell Death Ligand-1 Immune Checkpoint Inhibitor, in Patients With Advanced Urothelial Bladder Cancer. J Clin Oncol. 2016; 34(26): 3119-3125, doi: 10.1200/JCO.2016.67.9761, indexed in Pubmed: 27269937.

25. Antonia SJ, Villegas A, Daniel D, et al. PACIFIC Investigators. Durvalumab after Chemoradiotherapy in Stage III Non-Small-Cell Lung Cancer N Engl J Med. 2017; 377(20): 1919-1929, doi: 10.1056/NEJMoa1709937, indexed in Pubmed: 28885881.

26. Johnston RL, Lutzky J, Chodhry A, et al. Cytotoxic T-lymphocyte-associated antigen 4 antibody-induced colitis and its management with infliximab. Dig Dis Sci. 2009; 54(11): 2538-2540, doi: 10.1007/s10620-008-0641-z, indexed in Pubmed: 19104936

27. Kim HIn, Kim M, Lee SH, et al. Development of thyroid dysfunction is associated with clinical response to PD-1 blockade treatmen in patients with advanced non-small cell lung cancer. Oncoimmunology. 2017; 7(1), doi: 10.1080/2162402X.2017.1375642, indexed in Pubmed: 29296533

28. Cukier P, Santini FC, Scaranti M, et al. Endocrine side effects of cancer immunotherapy. Endocr Relat Cancer. 2017; 24(12): T331-T347, doi: 10.1530/ERC-17-0358, indexed in Pubmed: 29025857.

29. Stangierski A, Ruchała M, Krauze T, et al. Treatment of severe thyroid function disorders and changes in body composition. Endokrynol Pol. 2016; 67(4): 359-366, doi: 10.5603/EP.a2016.0025, indexed in Pubmed: 26884294.

30. Faje AT, Sullivan R, Lawrence D, et al. Ipilimumab-induced hypophysitis: a detailed longitudinal analysis in a large cohort of patients with metastatic melanoma. J Clin Endocrinol Metab. 2014; 99(11): 4078-4085, doi: 10.1210/jc.2014-2306, indexed in Pubmed: 25078147.

31. Albarel F, Gaudy C, Castinetti F, et al. Long-term follow-up of ipilimumab-induced hypophysitis, a common adverse event of the anti-CTLA- 4 antibody in melanoma. Eur J Endocrinol. 2015; 172(2): 195-204, doi: 10.1530/EJE-14-0845, indexed in Pubmed: 25416723.

32. Bronstein Y, Ng CS, Hwu P, et al. Radiologic manifestations of immune-related adverse events in patients with metastatic melanoma undergoing anti-CTLA-4 antibody therapy. AJR Am J Roentgenol. 2011; 197(6): W992-W1000, doi: 10.2214/AJR.10.6198, indexed in Pubmed: 22109345.

33. Tirumani $\mathrm{SH}$, Ramaiya $\mathrm{NH}$, Keraliya A, et al. Radiographic Profiling of Immune-Related Adverse Events in Advanced Melanoma Patients Treated with Ipilimumab. Cancer Immunol Res. 2015; 3(10): 1185-1192, doi: 10.1158/2326-6066.CIR-15-0102, indexed in Pubmed: 26100356.

34. Haanen J, Carbonnel F, Robert C, et al. Management of toxicities from immunotherapy: ESMO Clinical Practice Guidelines for diagnosis, treatment and follow-upt. Annals of Oncology. 2017; 28(Suppl 4) iv119-iv142, doi: 10.1093/annonc/mdx225.

35. Corsello S, Barnabei A, Marchetti P, et al. Endocrine Side Effects Induced by Immune Checkpoint Inhibitors. Clin Endocrinol Metab. 2013; 98(4): 1361-1375, doi: 10.1210/jc.2012-4075.

36. González-Rodríguez E, Rodríguez-Abreu D. Spanish Group for Cancer Immuno-Biotherapy (GETICA). Immune Checkpoint Inhibitors Review and Management of Endocrine Adverse Events. Oncologist. 2016; 21(7): 804-816, doi: 10.1634/theoncologist.2015-0509, indexed in Pubmed: 27306911.

37. Robert C, Long GV, Brady B, et al. Nivolumab in previously untreated melanoma without BRAF mutation. N Engl J Med. 2015; 372(4): 320-330 doi: 10.1056/NEJMoa1412082, indexed in Pubmed: 25399552.

38. Ribas A, Hamid O, Daud A, et al. Association of Pembrolizumab With Tumor Response and Survival Among Patients With Advanced Melanoma. JAMA. 2016; 315(15): 1600-1609, doi: 10.1001/jama.2016.4059, indexed in Pubmed: 27092830

39. Win MA, Thein KZ, Qdaisat A, et al. Acute symptomatic hypocalcemia from immune checkpoint therapy-induced hypoparathyroidism. Am J Emerg Med. 2017; 35(7): 1039.e5-1039.e7, doi: 10.1016/j.ajem.2017.02.048, indexed in Pubmed: 28363614 


\title{
Powikłania endokrynne immunoterapii nowotworów złośliwych
}

\author{
Aleksandra Król, Tomasz Gawlik, Barbara Jarząb \\ Zakład Medycyny Nuklearnej i Endokrynologii Onkologicznej, Centrum Onkologii — Instytut im. Marii Skłodowskiej-Curie, \\ Oddziat w Gliwicach, Gliwice, Polska
}

Artykuł jest tłumaczeniem pracy: Król A., Gawlik T., Jarząb B. Endocrine complications of cancer immunotherapy. Endokrynol Pol 2018; 69 (6): 722-727

Należy cytować wersję pierwotną.

Piśmiennictwo dostępne w wersji pierwotnej na stronach 726-727

\section{Streszczenie}

Immunoterapia z użyciem przeciwciał monoklonalnych — inhibitorów punktów kontroli immunologicznej — jest dynamicznie rozwijającą się dziedziną onkologii klinicznej, szansą dla wielu chorych z zaawansowaną i uogólnioną chorobą nowotworową. Aktywacja układu odpornościowego w zakresie czynności limfocytów T może równocześnie doprowadzić do reakcji autoimmunizacyjnej, niszczenia zdrowych narządów i do poważnych działań niepożądanych, w tym dotyczących układu wydzielania wewnętrznego.

W przedstawianej pracy omówiono możliwe powikłania endokrynne immunoterapii z użyciem obecnie stosowanych inhibitorów punktów kontroli immunologicznej (CTLA-4, PD-1, PD-L1/L2) z uwzględnieniem rodzaju i częstości działań niepożądanych, objawów oraz postępowania w zależności od stopnia toksyczności.

Brak właściwego rozpoznania patologii dotyczącej układu hormonalnego może w niekorzystnych okolicznościach zadecydować o ostatecznym niepowodzeniu leczenia i przesądzić o losie chorego.

Z uwagi na gwałtowny w ostatnich latach postęp w dziedzinie immunoterapii należy spodziewać się rosnącej liczby leczonych chorych. Perspektywa ta wymusza na nas, specjalistach endokrynologach, poznanie tej nowej i ważnej strategii leczenia onkologicznego. (Endokrynol Pol 2018; 69 (6): 728-733)
\end{abstract}

Słowa kluczowe: immunoterapia; inhibitory punktów kontroli immunologicznej; powikłania endokrynne

\section{Wstęp}

Naukowcy od wielu lat starali się wykorzystać możliwości własnego układu odpornościowego pacjenta do walki z chorobami, w tym nowotworami. Dopiero jednak zastosowanie w leczeniu przeciwciał monoklonalnych, tak zwanych inhibitorów punktów kontroli immunologicznej, przyniosło przełom w immunoterapii [1, 2].

Po raz pierwszy zastosowano nowy rodzaj terapii w leczeniu czerniaka (przeciwciało monoklonalne anty-CTLA-4 pod nazwą ipilimumab zaaprobowane przez U.S. Food and Drug Administration [FDA] w 2011 roku), a w kolejnych latach prowadzono liczne próby z użyciem przeciwciał przeciw nowym molekułom i w leczeniu kolejnych typów nowotworów, zwłaszcza raka nerki, niedrobnokomórkowego raka płuca, nowotworów głowy i szyi, w hematoonkologii i wielu innych. Amerykańskie Towarzystwo Onkologii Klinicznej (ASCO, American Society of Clinical Oncology) uznało immunoterapię za największe osiagnięcie lat 2015, 2016 i 2017 w zakresie walki z chorobami nowotworowymi. Liczba toczących się badań klinicznych oraz międzynarodowych konferencji wskazuje na ogromne zainteresowanie tematem $\mathrm{w}$ środowisku lekarskim i wielką nadzieję z nim związaną [3].

Aktywacja układu odpornościowego, będąca sednem leczenia, może prowadzić równocześnie do licznych powikłań narządowych, w tym dotyczących układu wydzielania wewnętrznego. Objawy uboczne zależą zarówno od rodzaju leku, jak i od indywidualnej predyspozycji chorego. Ich wstępne symptomy bywają niecharakterystyczne i mogą być przypisywane chorobie podstawowej. Znajomość możliwych powikłań endokrynnych immunoterapii jest konieczna dla bezpiecznego jej prowadzenia, a wobec rosnącej liczby leczonych chorych wiedza ta staje się niezbędna dla każdego endokrynologa. 


\section{Immunoterapia z użyciem inhibitorów punktów kontroli immunologicznej}

W warunkach zdrowia organizm ludzki dysponuje mechanizmami niszczącymi obce komórki, w tym nowotworowe. Komórka nowotworowa potrafi jednak unikać nadzoru immunologicznego, między innymi na drodze blokowania komórek układu odpornościowego, stając się dla układu odpornościowego niewidoczną. Próby wykorzystania własnego układu odpornościowego $\mathrm{w}$ celu walki z nowotworami podejmowano od ponad 100 lat, niestety bez spektakularnego rezultatu. Dopiero dokładniejsze poznanie funkcjonowania poszczególnych graczy skomplikowanej reakcji immunologicznej pozwoliło na rozwój metod immunoterapii w jej współczesnej postaci. Musimy zdać sobie sprawę, jak mizerna jeszcze nie tak dawno była nasza wiedza na temat roli poszczególnych rodzajów komórek immunokompetentnych, ich funkcji i wzajemnych powiązań, jak również mechanizmów ucieczki komórek nowotworowych spod nadzoru immunologicznego. Zdobycie tej wiedzy otworzyło drogę do opracowania modelu rozwiązań terapeutycznych opartych o przeciwciała monoklonalne blokujące tak zwane punkty kontroli immunologicznej. Dla właściwego działania układ odpornościowy musi dysponować zarówno sprawnym mechanizmem pobudzenia, jak i równie sprawnym mechanizmem hamowania nieograniczonej ekspansji, która mogłaby okazać się większym zagrożeniem dla organizmu niż sama choroba. Identyfikacja cząsteczek będących swoistymi ogranicznikami nadmiernej reakcji immunologicznej, czyli tak zwanych punktów kontroli immunologicznej, umożliwiła opracowanie leków, które potrafią skutecznie odblokować układ odpornościowy, a tym samym zwiększyć skuteczność działania własnych mechanizmów odpornościowych chorego. To właśnie odkrycie inhibitorów punktów kontroli immunologicznej stanowi przełom we współczesnej immunoterapii [4].

Aktywacja limfocytów T powoduje zwiększenie ekspresji na ich powierzchni białek odpowiedzialnych za hamowanie nadmiernej, a więc szkodliwej dla organizmu, aktywności układu odpornościowego. Białka te nazwano punktami kontroli immunologicznej (immune checkpoints). Należy do nich między innymi białko CTLA-4 (cytotoxic $T$ cell antygen-4) zidentyfikowane w 1987 roku. Ligandami dla CTLA-4 są - występujące na powierzchni komórek prezentujących antygen - cząsteczki CD80 i CD86. Słaba ekspresja CTLA-4 wiąże się z częstszym występowaniem chorób o podłożu autoimmunizacyjnym [5-7], w tym autoimmunizacyjnych chorób tarczycy $[8,9]$.

Przeciwciało monoklonalne skierowane przeciwko CTLA-4 było pierwszym lekiem z grupy inhibitorów punktów kontroli immunologicznej wprowadzonym do leczenia, zastosowano je $\mathrm{w}$ leczeniu rozsianego czerniaka po raz pierwszy $w$ ramach badań klinicznych w 2007 roku [10] i pod nazwą ipilimumab zostało przez FDA zaaprobowane w 2011.

Innym białkiem powierzchniowym będącym punktem kontroli immunologicznej jest PD-1 (programmed death receptor-1) ulegający ekspresji $\mathrm{w}$ limfocytach $\mathrm{T}$, limfocytach B i monocytach/makrofagach. Nadmierna aktywność limfocytów T wobec własnych tkanek jest hamowana poprzez wiązanie PD-1 z jego ligandem (PD-L1 lub PD-L2) obecnym na powierzchni komórek własnych organizmu. Obecność tego ligandu wykryto również na powierzchni komórek nowotworowych, co pozwala nowotworowi na ucieczkę przed nadzorem immunologicznym, a z drugiej strony pozwoliło na leczenie oparte o blokowanie zarówno PD-1 (np. niwolumab, pembrolizumab), jak i PD-L1 (np. atezolizumab, durwalumab). Leki będące inhibitorami obu wyżej wymienionych białek, $w$ tym skojarzone leczenie z CTLA-4, stanowią obecnie podstawowe sposoby leczenia czerniaka, raka nerki czy niedrobnokomórkowego raka płuca (ryc. 1). Skuteczność immunoterapii z użyciem przeciwciał wobec PD-1 i PD-L1 jest związana z ekspresją właściwego białka powierzchniowego na komórce nowotworu. Ważnym czynnikiem predykcyjnym jest również liczba mutacji w komórce guza. Zasadniczo, im większa liczba mutacji, neoantygenów nowotworowych o wysokiej immunogenności, czy też obecność niestabilności mikrosatelitarnej (MSI, microsatellite instability) lub tak zwanego deficytu naprawy błędnie sparowanych zasad azotowych w cząsteczce DNA (dMMR, mismatch repair deficient), tym częstsza i dłuższa odpowiedź na leczenie [11, 12].

Trwają badania nad inhibitorami innych cząsteczek obecnych na powierzchni limfocytów m.in. TIM-3 i LAG-3, jak również nad agonistami białek kostymulujących, które w przyszłości mogą znaleźć zastosowanie w immunoterapii nowotworów $[13,14]$.

\section{Toksyczność narządowa immunoterapii}

Uboczne niekorzystne efekty immunoterapii dotyczą potencjalnie wszystkich narządów. Jest to rodzaj toksyczności odmienny od obserwowanej po innych rodzajach leczenia przeciwnowotworowego, wiąże się specyficznie z mechanizmem zastosowanego leczenia opartego na odblokowaniu układu odpornościowego, infiltracją narządów aktywowanymi limfocytami $\mathrm{T}$ oraz ze specyficzną reakcją autoimmunizacyjną. Z uwagi na obecność punktów kontroli immunologicznej w całym organizmie, również niepożądane reakcje mogą dotyczyć każdego organu. Najczęstsze są w kolejności powikłania dotyczące skóry, układu 


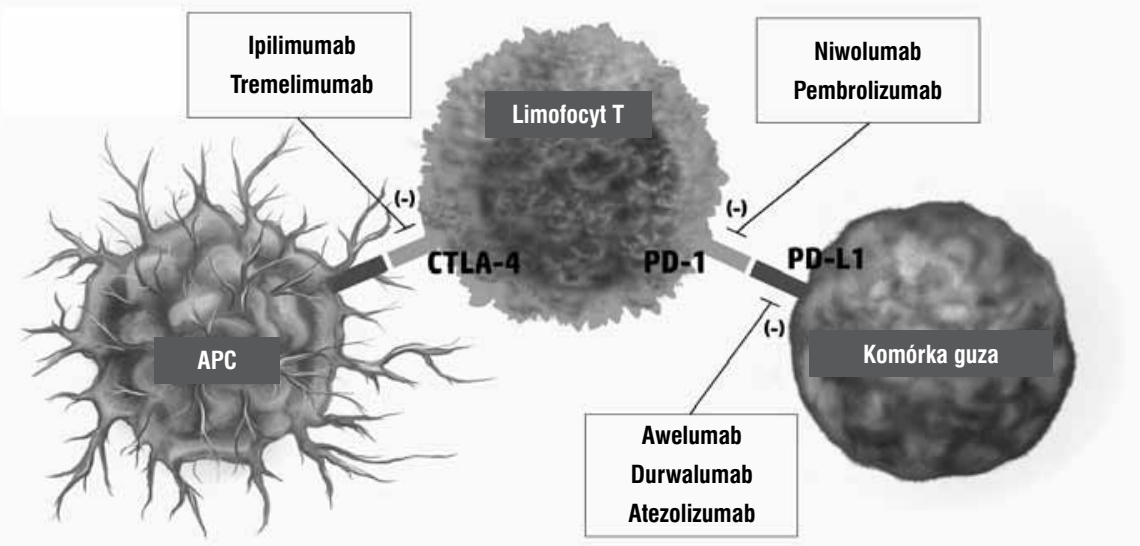

Rycina 1. Punkty kontroli immunologicznej będace celami immunoterapii. CTLA-4 — antygen 4 limfocytów T cytotoksycznych, PD-1 — receptor programowanej śmierci 1, PD-L1/L2 — ligand 1/2 receptora programowanej śmierci 1, APC — komórka prezentująca antygen

pokarmowego (w tym wątroby) i endokrynologicznego, rzadziej układu kostno-stawowego, oddechowego, sercowo-naczyniowego, nerwowego, nerek i dotyczące poszczególnych elementów gałki ocznej. Ich częstość oraz nasilenie toksyczności zależą od wielu czynników, zarówno po stronie leczenia (rodzaj zastosowanego leku, kombinacja leków), jak i pacjenta (ekspresja docelowego białka będącego punktem kontroli immunologicznej, a tym samym siła pobudzenia własnego układu odpornościowego, cechy osobnicze, stan układu odpornościowego przed rozpoczęciem leczenia, obecność chorób autoimmunizacyjnych) [15]. Trwają badania nad możliwością oceny wyjściowej pacjenta pod kątem spodziewanej toksyczności immunoterapii i znalezienia biomarkerów, które pozwolą na identyfikację zagrożonych chorych oraz wczesne wykrycie możliwych działań niepożądanych [16, 17]. Toczą się również badania dotyczące związku między nasileniem działań ubocznych immunoterapii a paleniem tytoniu czy dietą, a ściślej składem flory bakteryjnej jelit ( $g u t$ microbiome) $[18,19]$.

Jak wspomniano, powikłania immunoterapii mogą dotyczyć każdego narządu, występują z różną częstością w zależności od stosowanego schematu leczenia i pojawiają się w różnym czasie od rozpoczęcia immunoterapii. Toksyczność działań ubocznych (oceniana w ogólnie przyjętej skali Common Terminology Criteria for Adverse Events (CTCAE), która będzie omówiona niżej) ma decydujący wpływ na postępowanie z pacjentem, $\mathrm{w}$ tym kontynuowanie immunoterapii) [20-23].

Najczęstsze powikłania immunoterapii - powikłania skórne, pod postacią świądu, osutki, bielactwa, reakcji fotouczulenia, łysienie i inne - występują najwcześniej (od 2.-3. tygodnia od rozpoczęcia leczenia), doświadcza ich ponad 50\% leczonych chorych, częściej po inhibitorach CTLA-4. Najczęściej są łagodne, ustę- pują po zastosowaniu leków antyhistaminowych lub kortykosteroidów i nie wymagają przerwania leczenia przeciwnowotworowego.

Powikłania ze strony układu pokarmowego (biegunka, bóle brzucha, wymioty, endoskopowo stwierdzane zapalenie śluzówki jelita) są częste i o różnym nasileniu, zdecydowanie częstsze $\mathrm{w}$ trakcie terapii kombinowanej (anty-CTLA-4 w połączeniu z anty-PD-1), mogą sięgać wówczas $45 \%$ leczonych. W przypadku nasilonych objawów lub rozpoznania colitis powikłanie to wymaga przerwania immunoterapii, stosowania glikokortykosteroidów dożylnie, czasem dodatkowo leków immunosupresyjnych. Powikłania ze strony układu pokarmowego są zdecydowanie rzadsze przy stosowaniu nowszych inhibitorów anty-PD-L1 (np. dla durwalumabu oceniane na 2\% ) [24-26].

Powikłania wątrobowe powinny być monitorowane w trakcie każdego cyklu immunoterapii, jako że są częste i w początkowym okresie bezobjawowe, oznaczenie transaminaz jest wystarczające. Powikłania te dotyczą 5-10\% pacjentów poddanych monoterapii i około 25-30\% w trakcie terapii kombinowanej.

Na kolejnym miejscu pod względem toksyczności immunoterapii znajdują się powikłania endokrynne, którym poświęcony jest osobny rozdział. Częstość ogólna tych powikłań oceniana jest na około10\%, istnieje jednak znaczna różnica w częstości w zależności od stosowanego leku oraz rodzaju zajętego narządu. Ogólną cechą powikłań dotyczących układu wydzielania wewnętrznego jest ich niecharakterystyczny początek, skryty przebieg, aż do ciężkiego stopnia powikłań, często długi okres ustępowania, a nawet stałe upośledzenie czynności zajętego narządu, wymagające substytucji hormonalnej.

Powikłania dotyczące układu kostno-mięśniowego czy reumatologiczne opisano u 2-12\% leczonych, 
najczęściej pod postacią zapalenia naczyń (vasculitis), stawów lub mięśni (inflammatory arthritis, inflammatory myositis) są zwykle łagodne i dobrze odpowiadają na leczenie glikokortykosteroidami.

Mniej częste od powyższych są powikłania płucne (w tym zapalenia śródmiąższowe), powikłania nerkowe, często manifestujące się jedynie nieprawidłowym GFR, neurologiczne (poniżej 1\% chorych) pod postacią polineuropatii, zapalenia nerwu wzrokowego, zespołu Guillaina-Barrègo, miastenii czy aseptycznego zapalenia opon mózgowych. Zdecydowanie rzadkie są objawy niepożądane ze strony serca (głównie zaburzenia rytmu o przebiegu klinicznym podobnym do zapalenia mięśnia sercowego czy kardiomiopatii), trzustki i struktur gałki ocznej (keratitis, uveitis, conjunctivitis, episcleritis).

Pojawienie się objawów ubocznych immunoterapii, jeśli tylko ich nasilenie nie wymaga przerwania leczenia, może wręcz stanowić o większej skuteczności stosowanego leczenia, o czym przekonują dotychczasowe obserwacje; trwają badania prospektywne nad związkiem wystąpienia objawów ubocznych a efektem leczenia [20-23, 27].

\section{Wpływ immunoterapii na układ hormonalny}

Endokrynne objawy uboczne immunoterapii są częste i pojawiają się zwykle w okresie 7-20 tygodni od rozpoczęcia leczenia. Immunoterapia $\mathrm{z}$ zastosowaniem monoterapii anty-CTLA-4 lub terapii łączonej z użyciem tego przeciwciała może prowadzić do zaburzeń czynności przysadki w przebiegu jej zapalenia, podczas gdy stosowanie leczenia anty-PD-1 i anty-PD-L1/L2 częściej prowadzi do zaburzeń funkcji tarczycy, przede wszystkim jej niedoczynności. Każdy narząd wydzielania wewnętrznego może być dotknięty działaniem niepożądanym, w tym tak kluczowe dla stanu pacjenta jak kora nadnerczy, zarówno w mechanizmie wtórnej, jak i pierwotnej niewydolności, zagrażającej życiu chorego. Wśród rzadziej występujących powikłań wymienia się zaburzenia gospodarki węglowodanowej pod postacią cukrzycy typu 1 czy niedoczynności przytarczyc [28].

Ważną cechą powikłań endokrynnych jest ich niecharakterystyczny początek, który może być wiązany z chorobą podstawową. Należy pamiętać, iż w odróżnieniu od sytuacji, z którymi w swojej codziennej praktyce spotyka się endokrynolog, nie mamy do czynienia z pacjentem dotychczas zdrowym, u którego objawy pojawiają się nagle. Pierwsze symptomy dysfunkcji hormonalnej pod postacią zmęczenia, osłabienia, braku apetytu, zmiany masy ciała mogą więc zostać powiązane $z$ chorobą nowotworową trwającą od dłuższego czasu [28, 29]. Objawów zaburzeń hormonalnych należy więc poszukiwać aktywnie, przede wszystkim przeprowadzać dokładny wywiad z chorym podczas każdego kolejnego podania leku i zlecać badania biochemiczne w razie wskazań

Jak wzmiankowano wyżej, nasilenie działań niepożądanych każdego rodzaju leczenia przeciwnowotworowego oceniane jest w skali 1-5 CTCAE aktualna wersja $5.0 \mathrm{z}$ listopada 2017). Stopień pierwszy oznacza bezobjawowe odchylenia w badaniach, stopień drugi objawy umiarkowane, trzeci - ciężkie, najczęściej z konieczną hospitalizacją, czwarty - objawy zagrażające życiu chorego, stopniem piątym oznaczono zgon pacjenta wywołany toksycznością leczenia. Endokrynne objawy uboczne najczęściej mieszczą się w skali ciężkości 1-2 i nie wymagają definitywnego przerwania leczenia. Jednak wielu chorych doświadcza cięższych działań niepożądanych, zwłaszcza w sytuacji opóźnionego ich rozpoznania, co skutkuje koniecznością przerwania leczenia przeciwnowotworowego, stosowania wysokich dawek glikokortykosteroidów, a nawet może stanowić bezpośrednie zagrożenie życia chorego (1-2\% chorych) [28].

\section{Powikłania przysadkowe}

Dysfunkcja przysadki jako powikłanie immunoterapii opisywana jest przede wszystkim w trakcie stosowania przeciwciała anty-CTLA-4 (ipilimumab) lub terapii kombinowanych z jego udziałem, z częstością 1,5-17\% leczonych, częściej u mężczyzn i u osób starszych. Objawy pojawiają się najczęściej po około dwóch miesiącach od rozpoczęcia leczenia i mogą wynikać z tak zwanego efektu masy, spowodowanego powiększeniem przysadki (bóle głowy, zaburzenia widzenia) lub z niedoborów hormonalnych (osłabienie, zmęczenie, brak apetytu). Objawy miejscowe wymagają różnicowania z przerzutami do mózgowia i zapaleniem opon mózgowych (tzw. aseptyczne zapalenie opon) [30, 31].

U większości pacjentów pojawia się charakterystyczny obraz w badaniu MR pod postacią powiększenia gruczołu, wynikającego z nacieczenia komórkami immunokompetentnymi [32, 33]. Wskaźniki biochemiczne wykazują typową niewydolność przedniego płata przysadki w zakresie wszystkich osi, rzadziej niedobór hormonu wzrostu czy prolaktyny. Nie stwierdzono przypadków niewydolności tylnego płata przysadki. Każda toksyczność powyżej stopnia 2 (w tym przypadku oznacza to każdy przypadek z objawami miejscowymi oraz każdy przypadek z objawową dysfunkcją hormonalną) wymaga przerwania immunoterapii. W przypadku dolegliwości wynikających z efektu masy, a szczególnie zaburzeń widzenia, wymagana jest pilna interwencja pod postacią dożylnego zastosowania glikokortykosteroidów 
(np. hydrokortyzon 50-100 mg 3-4 razy dziennie lub metyloprednizolon w dawce równoważnej), a w przypadku toksyczności w stopniu umiarkowanym zastosowanie glikokortykoidów doustnie (np. hydrokortyzon 20-30 mg/d. w dawkach podzielonych lub prednizon czy prednizolon w dawkach równoważnych). Substytucję innymi hormonami, których niedobór stwierdzono na podstawie oznaczeń biochemicznych, stosuje się typowo, jak w niedoczynności przysadki. Dla niedoczynności przysadki będącej powikłaniem immunoterapii charakterystyczne jest długotrwałe utrzymywanie się dysfunkcji hormonalnej, mimo zaprzestania stosowania immunoterapii i mimo poprawy w obrazie MR. Dotyczy to zwłaszcza niewydolności kory nadnerczy, w drugiej kolejności niedoczynności tarczycy i gonad. Oznacza to konieczność przewlekłego leczenia substytucyjnego.

Niedoczynność przysadki jako powikłanie występuje sporadycznie $\mathrm{w}$ trakcie leczenia anty-PD-1 czy anty-PD-L1 u mniej niż $1 \%$ chorych, w tym na przykład w przypadku durwalumabu $<0,1 \%$. Oznacza to, że o powikłaniach ze strony przysadki należy pamiętać przede wszystkim $u$ chorych leczonych ipilimumabem $\mathrm{w}$ monoterapii lub $\mathrm{w}$ terapii kombinowanej $[28,30$, $31,34]$.

\section{Wpływ immunoterapii na funkcję tarczycy}

Zaburzenia funkcji tarczycy, głównie pod postacią jej pierwotnej niedoczynności, występują często (>10\% leczonych) po stosowaniu inhibitorów PD-1 i PD-L1/L2 (niwolumab, pembrolizumab, atezolizumab, durwalumab). W przypadku anty-CTLA-4, w zależności od dawki leku, obserwowano zaburzenia tarczycowe odpowiednio u 1-5\% chorych przy dawce standardowej lub do $10 \%$ chorych przy dawce ipilimumabu $10 \mathrm{mg} / \mathrm{kg}$. Terapia łączona (np. ipilimumab + niwolumab) wiąże się ze wzrostem ryzyka powyżej 20\% leczonych. Należy pamiętać o występowaniu dodatkowo wtórnej niedoczynności tarczycy w przebiegu zapalenia przysadki, o czym wspominano powyżej.

Możliwe niepożądane reakcje ze strony tarczycy obejmują niedoczynność trwałą i przejściową, nadczynność w przebiegu zapalenia (painless thyroiditis), ujawnienie choroby Gravesa, w tym przełom tarczycowy czy orbitopatię. U większości chorych z powikłaniami tarczycowymi stwierdza się podwyższone stężenia przeciwciał przeciwtarczycowych (anty-TPO lub anty-Tg). Nie ma jak dotąd przekonujących dowodów na to, czy chorzy z wyjściowo podwyższonymi przeciwciałami są bardziej narażeni na ryzyko zaburzeń funkcji tarczycy lub ich dłuższe utrzymywanie się.

Czas od rozpoczęcia leczenia do pojawienia się objawów ze strony tarczycy jest różnie długi, od kilku dni do ponad roku, z medianą około trzy miesiące, objawy występują częściej u kobiet, większość przypadków nie przekracza drugiego stopnia toksyczności i nie wymaga przerwania immunoterapii.

Decydując o leczeniu powikłań tarczycowych, należy kierować się oznaczeniami hormonów oraz objawami dysfunkcji. W przypadku bezobjawowego niewielkiego wzrostu TSH $(<10 \mu \mathrm{IU} / \mathrm{ml})$ nie ma konieczności włączenia substytucji ani tym bardziej przerywania immunoterapii, należy monitorować chorego przed każdym kolejnym cyklem leczenia. Nadczynność tarczycy wymaga różnicowania między zapaleniem a chorobą Gravesa, zalecane jest wykonanie oznaczenia przeciwciał, w tym przeciw receptorowi TSH, scyntygrafii tarczycy z oceną jodochwytności oraz włączenie leczenia w zależności od rozpoznania (glikokortykosteroidy, beta-adrenolityki, rzadziej tyreostatyk).

Należy pamiętać o możliwości wtórnych zaburzeń związanych z niedomogą przysadki i w każdym przypadku obniżonego stężenia TSH i niskich stężeń wolnych hormonów zlecić dodatkowo diagnostykę osi nadnerczowej.

Pierwotne zaburzenia czynności tarczycy mają często charakter przejściowy, co wymaga monitorowania chorego nie tylko w trakcie stosowanej immunoterapii, ale i po jej zakończeniu lub zmianie leku [28, 35, 36].

\section{Upośledzenie funkcji nadnerczy jako skutek immunoterapii}

Jak wspomniano powyżej niewydolność nadnerczy może być pierwszą manifestacją niewydolności przysadki w przebiegu immunoterapii. Jej częstość jest porównywalna z samym zapaleniem przysadki, jako że występuje $\mathrm{w}$ ponad $75 \%$ chorych dotkniętych zaburzeniami przysadkowymi. W trakcie immunoterapii może pojawić się również pierwotna niewydolność kory nadnerczy, jest jednak znacznie rzadsza (do $2 \%$ leczonych, w większości badań poniżej 1\%). Pierwszym zwiastunem rozwijającej się niedoczynności nadnerczy jest często bezobjawowa hiponatremia, należy więc zwracać szczególną uwagę na stężenia elektrolitów u leczonych chorych. U większości pacjentów pojawienie się powikłania ze strony kory nadnerczy oznacza przerwanie immunoterapii, jako że u większości leczonych występuje toksyczność 3. stopnia, wymagająca hospitalizacji. W części przypadków opisywano również powiększenie nadnerczy w badaniach obrazowych spełniające radiologiczne kryteria adrenalitis. Leczenie powikłania nie różni się od typowej substytucji w przypadku innych rodzajów pierwotnej niewydolności kory nadnerczy, należy pamiętać o uzupełnieniu mineralokortykosteroidów [28, 36]. 


\section{Inne rzadsze powikłania endokrynne}

Cukrzyca jest rzadkim powikłaniem immunoterapii. Występuje z częstością poniżej 1\% leczonych, głównie $\mathrm{u}$ chorych stosujących przeciwciała anty-PD-1 (np. niwolumab $-0,9 \%$, pembrolizumab $-0,2 \%$, awelumab $-0,1 \%), \mathrm{w}$ większości o stopniu toksyczności 3. z glikemią powyżej $250 \mathrm{mg} \%$, wymaga wówczas przerwania immunoterapii i leczenia insuliną, jak w cukrzycy typu 1.

Pojedyncze opisy przypadków dotyczą innych możliwych działań ubocznych immunoterapii, na przykład ostrej hipokalcemii w przebiegu niedoczynności przytarczyc $w$ trakcie terapii łączonej (ipilimumab + niwolumab) [37-39].

\section{Współpraca endokrynologa z onkologiem}

Leczenie z użyciem inhibitorów punktów kontroli immunologicznej jest prowadzone przez wyspecjalizowane centra onkologiczne, obecnie w Polsce przez około 20 ośrodków. Chorymi zajmują się specjaliści onkolodzy kliniczni i to na nich ciąży główna odpowiedzialność za właściwą kwalifikację chorych i ich bezpieczne leczenie, $\mathrm{w}$ tym za wczesne i trafne rozpoznanie działań ubocznych. Programy lekowe zawierają wskazania do stosowania przesiewowych badań biochemicznych, $\mathrm{w}$ tym z zakresu endokrynologii, obejmujące najczęściej spodziewane powikłania. Jak wspomniano powyżej, część niepożądanych działań ubocznych mieści się w stopniu toksyczności 1.-2. i często nie wymaga przerwania leczenia. Często też prowadzący chorego onkolog sam wdraża właściwe leczenie, tak jest na przykład w przypadku łagodnej pierwotnej niedoczynności tarczycy. W ośrodkach dysponujących możliwością konsultacji specjalistycznych pacjentem może zajmować się wielo- specjalistyczny zespół, co z pewnością stanowi ogromne wsparcie dla onkologa klinicznego, zwłaszcza w przypadkach trudniejszych, wymagających pogłębionej wiedzy z zakresu konkretnej specjalności. Pacjent z pełnoobjawową niedoczynnością przysadki czy pierwotną niedoczynnością kory nadnerczy z pewnością wymaga specjalistycznej pomocy endokrynologa. O przerwaniu immunoterapii decyduje prowadzący onkolog, jednak opinia endokrynologa jest znacząca.

Jak wspomniano, wiele niepożądanych działań ubocznych z zakresu endokrynologii ma charakter trwały, co oznacza, że mimo zakończenia, przerwania czy zmiany leczenia przeciwnowotworowego, chorzy będą podlegali leczeniu substytucyjnemu pod kontrolą specjalisty endokrynologa $\mathrm{w}$ miejscu zamieszkania.

\section{Podsumowanie}

Należy mieć nadzieję, że postęp w immunoterapii doprowadzi do powstania leków mających mniej istotnych działań ubocznych. Tymczasem jednak stosowanie terapii łączonych oraz coraz szersze włączanie immunoterapii $\mathrm{w}$ kolejnych rodzajach nowotworów sprawia, iż liczba leczonych chorych gwałtownie wzrasta. W najbliższym czasie zarówno onkolodzy, jak i endokrynolodzy będą musieli zmierzyć się z wieloma przypadkami powikłań endokrynnych immunoterapii. Ważne jest, żeby specjaliści obu dyscyplin potrafili połączyć wysiłki i wspólnie prowadzić leczenie z korzyścią dla chorych.

Większości endokrynologów temat immunoterapii nowotworów złośliwych może wydawać się dziś odległy, tymczasem immunoterapia wraz ze swoimi korzyściami i zagrożeniami stoi u drzwi, a to wymaga od nas właściwego przygotowania. 